\title{
Hubungan Pengetahuan Perawat Tentang Konsep Dasar K3 Dalam Memberikan Asuhan dan Pelayanan Keperawatan
}

Fitri Rahman Batubara

\author{
Fitri.batubara.fr@gmail.coom
}

\begin{abstract}
Abstrak
Rumah sakit merupakan tempat kerja yang berisiko tinggi untuk terjadinya kecelakaan kerja. Pengetahuan kesehatan dan keselamatan kerja (K3) yang baik dapat menurunkan angka kecelakaan kerja hingga tercapainya zero accident. Perawat merupakan tenaga kesehatan yang sering kontak dengan pasien sehingga diharapkan mampu menerapkan K3 dengan baik. Pelaksanaan Keselamatan dan Kesehatan Kerja (K3) adalah salah satu bentuk upaya untuk menciptakan tempat kerja yang aman, sehat, bebas dari pencemaran lingkungan. Metode: Metode yang digunakan dalam kajian ini adalah Literature review, dengan menganalisis, eksplorasi, kajian bebas pada artikel, jurnal, text book, maupun e-book yang releven dan berfokus pada metode pembelajaran klinik yang mempengaruhi kemampuan berpikir kritis mahasiswa keperawatan.
\end{abstract}

Kata Kunci : Pengetahuan Perawat, Konsep Dasar K3 
1. Latar Belakang

Kesehatan dan Keselamatan

Kerja (K3) adalah upaya untuk memberikan jaminan keselamatan dan meningkatkan derajat kesehatan pekerja dengan cara pencegahan kecelakaan dan penyakit akibat kerja (PAK), pengendalian bahaya di tempat kerja, promosi kesehatan, pengobatan, dan rehabilitasi. Berdasar atas data Badan Penyelenggara Jaminan Sosial (BPJS) Ketenagakerjaan, hingga akhir 2015 telah terjadi kecelakaan kerja sebanyak 105.182 kasus di Indonesia. Jumlah kecelakaan akibat kerja di Jawa Barat pada tahun 2014 mencapai 1713 kasus dan di Pulau Jawa sebesar 4.663 kasus. Kecelakaan kerja dapat dipengaruhi oleh lama kerja, usia, dan pendidikan seseorang. Data Bureau of Labour Statistics menyebutkan sebanyak 253.700 kecelakaan kerja terjadi di rumah sakit Amerika Serikat pada tahun 2011. Kecelakaan kerja yang terjadi di rumah sakit dapat berupa tertusuk jarum suntik, cedera muskuloskeletal, dan stres psikis. Angka kecelakaan kerja tertinggi pada tenaga kesehatan adalah perawat, yaitu sebesar empat kali lipat dibanding dengan kecelakaan kerja tenaga kesehatan lain.

Penerapan K3 di Indonesia diatur oleh Undang- Undang Republik Indonesia Nomor 13 Tahun 2003 tentang Ketenagakerjaan, sedangkan K3 rumah sakit (K3RS) diatur oleh KEPMENKES RI Nomor 1087/MENKES/SK/VIII/2010. K3 pada umumnya bertujuan melindungi keselamatan dan kesehatan pekerja ataupun buruh dalam mewujudkan produktivitas kerja yang optimal. Tujuan diterapkannya K3RS adalah terciptanya cara kerja, lingkungan kerja yang sehat, aman, nyaman, dan dalam rangka meningkatkan derajat kesehatan karyawan RS. Pengetahuan K3RS yang baik diharapkan mampu menekan angka kecelakaan kerja karena individu tersebut

dapat menerapakan tindakan yang sesuai dengan pengetahuan K3 yang dimilikinya.

Upaya penerapan K3 di rumah sakit menyangkut tenaga kerja, cara/metode kerja, alat kerja, proses kerja, dan lingkungan kerja yang meliputi peningkatan, pencegahan, pengobatan, dan 
pemulihan. Tenaga kesehatan yang sering berkontak langsung dengan pasien adalah perawat. Tingkat pengetahuan $\mathrm{K} 3$ perawat sangat penting dalam menjaga keselamatan pasien dan diri perawat itu sendiri sesuai dengan penelitian terdahulu bahwa didapatkannya hubungan bermakna antara tingkat pengetahuan perawat dengan tindakan keselamatan terhadap pasien.

faktor yang dapat memengaruhi tingkat pengetahuan K3 pada penelitian ini adalah, pendidikan, usia, dan lama kerja.

\section{Metode}

Metode yang digunakan dalam penulisan ini adalah metode kajian bebas dimana metode ini berwilayah lebih sempit dengan tingkat variasi yang rendah, namun dari penulisan ini dapat berkembang menjadi lebih luas. Metode kajian bebas ini merupakan metode yang dilakukan untuk melakukan penulisan yang dikumpulkan dari beberapa sumber seperti buku teks, buku referensi jurnal dan e-book, dan juga dibandingkan dengan jurnal yang berhubungan dengan "pentingnya peran keluarga dalam pencegahan pasien di rumah sakit". Sehingga pembaca dapat mengerti informasi yang sudah ditulis dan dapat memahami pentingnya peran keluarga dalam pencegahan pasien di rumah sakit.

\section{Hasil}

Reputasi perusahaan merupakan modal pokok yang mencerminkan pada kemampuan perusahaan untuk memuaskan ke Keselamatan dan kesehatan kerja (K3) adalah suatu program yang dibuat pekerja maupun pengusaha sebagai upaya mencegah timbulnya kecelakaan akibat kerja dan penyakit serta tindakan antisipatif apabila terjadi kecelakaan dan penyakit kerja. Tujuannya adalah untuk menciptkan tempat keja yang nyaman, dan sehat sehingga dapat menekan serendah mungkin resiko kecelakaan dan penyakit. Adapun mengenai tujuan keselamatan dan kesehatan kerja (K3) dijelaskan pula oleh suatu undangundang semata memberikan jamian kepada karyawan dari perusahaan itu sendiri dan juga meningkatkan kesejateraan secara bersama yang dapat menjalankan produktifitas dalam bidang usaha yang telah dikelolanya 
secara baik sehingga dapat mencapai tujuan dari perusahaan itu sendiri.

Pengetahuan yang baik tentang penerapan $\mathrm{K} 3$, dapat meminimalisir atau mengurangi penyakit kerja atau kecelakaan akibat kerja. Pengetahuan tersebut meliputi bagaimana upaya pencegahan terjadinya kecelakaan kerja. Perawat yang memiliki Pengetahuan yang kurang dapat menyebabkan terjadinya kecelakaan kerja. Lama pekerjaan perawat juga menentukan tingkat efektivitas pelaksanaan konsep dasar K3. Perawat yang sudah memiliki banyak pengalaman tentu akan dapat mudah dalam penerapan kesehatan dan keselamatan kerja, Hal jni dikarenakan perawat sudah pernah dan terbiasa dalam melaksanakan prosedur K3 dan sudah banyak mengamati kesalahankesalahan yang terjadi akibat dari kelalaian karena tidak melaksanakan prosedur kesehatan dan keselamatan kerja ketika bekerja.

Sikap perawat juga berpengaruh dalam pelaksanaan konsep dasar kesehatan dan keselamatan kerja. Dalam melaksanakan manajemen K3 perawat harus memiliki sikap yang sesuai dengan nilai-nilai kesehatan dimana perawat yang memiliki nilai positif yang ada dalam dirinya dapat menjadi pendorong perilaku sehat dan menjadi upaya dalam meningkatkan kesehatan dan keselamatan selama bekerja. Dalam upaya pencegahan kecelakaan kerja dan penyakit akibat kerja, Maka perawat harus memiliki sikap yang pro aktif untuk mengaplikasikan ilmu yang dimilikinya tentang pelaksanaan kesehatan dan keselamatan kerja. Semakin pro aktif mengaplikasikan ilmu yang dimilikinya, maka akan semakin bersikap positif tentang pelaksanaan K3 sehingga akan mengurangi kejadian kecelakaan kerja dan penyakit akibat kerja.

Perawat dengan persepsi yang baik memiliki kemungkinan lebih besar untuk patuh dibandingkan dengan perawat dengan persepsi kurang baik. Hal ini dikarenakan, ketika perawat sudah memiliki persepsi yang baik terhadap pentingnya kesehatan dan keselamatan kerja, Maka perawat akan memberikan perhatian terhadap pelaksanaan kesehatan dan keselamatan kerja.

\section{Pembahasan}

Notoadmodjo (2010) mendefinisikan pengetahuan sebagai hasil pengindraan manusia, atau hasil tahu seseorang 
terhadap objek melalui indra yang dimilikinya (mata, hidung, telinga, dan sebagainya), sehingga menghasilkan pengetahuan yang dipengaruhi oleh intensitas perhatian dan persepsi terhadap objek.

Pengetahuan dibagi atas 6 tingkatan, diantaranya:

\section{Tahu (know)}

Tahu diartikan hanya sebagai memanggil (recall) memori yang telah ada sebelumnya setelah mengamati sesuatu. Misalnya: tahu bahawabuah jeruk banyak mengandung vitamin $\mathrm{C}$, penyakit demam berdarah ditularkan melalui nyamuk Aedes aegeptii, dan sebagainya. Untuk mengetahui dan mengukur bahwa orang tahu sesuatu dapat mmenggunakan pertanyaan-pertanyaan.

\section{Memahami (comprehension)}

Memahami suatu objek bukan sekadar tahu terhadap objek tersebut, tidak sekedar menyebutnya, tetapi orang tersebut harus dapat menginterpretasikan secara benar tentang objek yang diketahuinya tersebut.

\section{Aplikasi}

Aplikasi diartikan apabila orang yang telah memahami objek yang dimaksud dapat menggunakan atau mengaplikasikan prinsip yang diketahui tersebut pada situasi yang lain

\section{Analisis}

Analisis adalah kemampuan seseorang untuk menjabarkan dan memisahkan, kemudian mencari hubungan antara komponenkomponen yang terdapat dalam suatu masalah atau objek yang diketahuinya.

\section{Sintesis}

Sintesis menunjukkan suatu kemampuan seseorang untuk merangkum atau meletakkan dalam suatu hubungan yang logis dari komponen- komponen pengetahuan yang dimiliki. Dengan kata lain, sintesis adalah suatu kemampuan untuk menyusun formulasi baru dari formulasiformulasi yang sudah ada.

\section{Evaluasi}

Evaluasi berkaitan dengan kemampuan seseorang untuk melakukan justifikasi atau penilaian terhadap suatu objek tertentu.Penilaian ini dengan 
sendirinya didasarkan pada suatu kriteria yang ditentukan sendiri atau norma-norma yang berlaku di masyarakat.

Pengertian keselamatan dan kesehatan kerja menurut Keputusan Menteri Tenaga Kerja R.I. No. Kep. 463/MEN/1993 tentang keselamatan dan kesehatan kerja adalah upaya perlindungan yang ditujukan agar tenaga kerja dan orang lainnya di tempat kerja/perusahaan selalu dalam keadaan selamat dan sehat, serta agar setiap sumber produksi dapat digunakan secara aman dan efisien. Konsep dasar mengenai keselamatan dan kesehatan kerja adalah perilaku yang tidak aman karena kurangnya kesadaran pekerja dan kondisi lingkungan yang tidak aman.

Gerakan Keselamatan Pasien Rumah Sakit (GKP-RS) atau yang dikenal dengan sebutan patient safety merupakan suatu proses pemberian pelayanan rumah sakit terhadap pasien yang lebih aman. Proses ini mencegah terjadinya cedera yang disebabkan oleh kesalahan akibat melaksanakan suatu tindakan atau tidak mengambil tindakan yang seharusnya diambil (Depkes RI, 2006, p.10). Tujuan utama penerapan patient safety di rumah sakit adalah mencegah dan mengurangi terjadinya Insiden Keselamatan Pasien (IKP) dalam pelayanan kesehatan. IKP merupakan kejadian atau situasi yang dapat berpotensi atau mengakibatkan cedera pada pasien yang seharusnya tidak terjadi. IKP ini meliputi Kejadian yang Tidak Diharapkan (KTD), Kejadian Nyaris Cedera (KNC), Kejadian Potensial Cedera (KPC), dan Kejadian Sentinel (suatu KTD yang mengakibatkan kematian atau cedera yang serius). Angka IKP di Indonesia masih sulit diperoleh, namun IKP dapat saja terjadi dalam pelayanan kesehatan di rumah sakit.

kesalahan yang mengakibatkan pasien cedera dapat berupa ketidaktepatan identifikasi pasien yang berakibat kesalahan atau keterlambatan diagnosis, kegagalan dalam bertindak, kesalahan pengobatan, dan kesalahan dosis atau metode dalam pemberian obat. Sasaran keselamatan pasien lainnya yang perlu diperhatikan untuk 
menghindari cedera pada pasien berupa peningkatan keamanan obat yang perlu diwaspadai, pengurangan resiko infeksi terkait pelayanan kesehatan, dan pengurangan resiko jatuh. Upaya penerapan patient safety sangat tergantung dari pengetahuan perawat. Apabila perawat menerapkan patient safety didasari oleh pengetahuan yang memadai, maka perilaku patient safety oleh perawat tersebut akan bersifat langgeng (long lasting).

Seorang perawat dalam memberikan asuhan keperawatan harus memiliki pengetahuan yang benar, keterampilan, dan sikap untuk menangani kompleksitas perawatan kesehatan. Tanpa pengetahuan yang memadai, tenaga kesehatan termasuk perawat tidak bisa menerapkan dan mempertahankan budaya keselamatan pasien. Pengetahuan seseorang erat hubungannya dengan tindakan seseorang dalam memenuhi kewajibannya, sehingga pendidikan lanjut sangat penting dalam usaha meningkatkan perawat dalam memperoleh pengetahuan.

Keselamatan pasien bagi perawat tidak hanya merupakan pedoman tentang apa yang seharusnya dilakukan, namun keselamatan pasien merupakan komitmen yang tertuang dalam kode etik perawat dalam memberikan pelayanan yang aman, sesuai kompetensi, dan berlandaskan kode etik bagi pasien (Canadian Nurse Association, 2004). Pemberian pelayanan yang aman harus didahului dengan pemahaman materi keselamatan pasien rumah sakit yang mengacu standar internasional pada Joint Commission International (JCI). JCI merupakan salah satu lembaga akreditasi internasional rumah sakit yang telah diakui oleh dunia. Fokus utama JCI adalah meningkatkan keselamatan perawatan pasien melalui penyediaan jasa akreditasi dan sertifikasi serta melalui layanan konsultasi dan pendidikan dengan tujuan membantu organisasi menerapkan solusi praktis dan berkelanjutan.

Sejak tahun 2012, akreditasi JCI mulai berorientasi pada paradigma baru yang berfokus pada keselamatan pasien. Akreditasi JCI akan mendukung perilaku perawat dalam 
menerapkan IPSG (International

Patient Safety Goals).
Dengan demikian dapat
dijelaskan bahwa semakin tinggi
pengetahuan perawat tentang
penerapan keselamatan pasien
(patient safety), diharapkan
semakin tinggi pula perawat dalam
memahami pentingnya penerapan
keselamatan pasien (patient safety)
yang diberikan kepada pasien
dalam pelayanan keperawatan.

\section{Penutup}

Kesimpulan penelitian yaitu :

1. Terdapat hubungan pengetahuan perawat tentang penerapan kesehatan dan keselamatan kerja (K3) di rumah sakit dalam memberikan asuhan dan pelayanan keperawatan.

2. Terdapat hubungan sikap perawat dengan penerapan kesehatan dan keselamatan kerja (K3) pada di Rumah Sakit dalam memberikan asuhan dan pelayanan keperawatan. 


\section{Referensi}

Edwina Rudiyarti. 2017. Hubungan

Nida D. H., Titik R., Yuli S. 2017.

Pengetahuan Keselamatan dan

Kesehatan Kerja dan Sikap

Penggunaan Alat Pelindung Diri

Dengan Kejadian Kecelakaan

Kerja Pada Pengrajin Pisau Batik

di PT. X. Journa of Industrial

Hygiene and Occupational Health, 2(1).

Ernawati, N., \& Nurlelawati, E.

2017. FAKTOR-FAKTOR YANG

BERHUBUNGAN DENGAN

PELAKSANAAN PENERAPAN

K3 PADA KESEHATAN

PERMATA HUSADA

FEBRUARI. Jurnal Akademi

Keperawatan Husada Karya Jaya, 3(1).

Mantiri, E.Z.R.A. Pinontoan, O.R.

Mandey, S. 2020. Faktor Psikologi

dan Perilaku Dengan Penerapan

Manajemen Keselamatan dan

Kesehatan Kerja Rumah Sakit.

Indonesian Journal of Public

Health and Community Medicine, Vol. 1(3). 19-27.

Nazirah, R. Yuswardi. 2017.

Perilaku Perawat Dalam Penerapan

Manajemen Kesehatan dan

Keselamatan Kerja (K3) Di Aceh.

Idea Nursing Journal, Vol. 8(3). 
Rejeki, S. (2015). SANITASI, HIGIENE DAN KESELAMATAN KERJA

(K3). Bandung: Rekayasa Sains.

Simamora, R. H. 2011.

CONFLICT OF ROLE NURSE WITH THE UNIT OF RSD DR. JEMBER. RELATIONSHIP PERFORMANCE IN EMERGENCY HOSPITALS
SOEBANDI. The Journal of Malaysian Nursing, 3(2), 23-32.

Tukatman, Sulistiawati, Purwaningsi, Nursalam. 2015. Analisis Keselamatan dan Kesehatan Kerja Perawat Dalam Penanganan Pasien Di Rumah Sakit Benyamin Guluh Kabupaten Kolaka. Jurnal Ners, 10 (2). 